\title{
Chemistry of Phosphorus Ylides, Part 30. Reaction of Camphorquinone Derivatives with Active Phosphacumulenes and Stabilized Phosphonium Ylides
}

\author{
S. S. Maigali", H. A. Abdel - Malek and F. M. Soliman \\ Department of Organometallic and Organometalloid Chemistry, \\ National Research Centre, Giza, 12622, Egypt.
}

\begin{abstract}
THE REACTION of the bifunctional camphorquinone(1), its monophenylhydrazone (13) and monooxime (16) with the active phosphacumulenes (2) was performed. Phosphanylidene- cyclobutylidenes (5), azitidine bicyclo heptanones (14) and phosphanylidenes (17) were obtained, respectively. On the other hand, the stabilized phosphonium ylides (6) react with the above mentioned substrates (1, 13, and 16) to give the corresponding oxaphosphetane (8), phosphanylidene (10) oxatricycloundecadiene (12), azaphosphetidines (15) and the azatricyclo- undecadienone (19).
\end{abstract}

Keywords: Camphorquinone derivatives, phosphonium ylides, Phosphanylidene cyclobutylidenes, Oxaphosphetane and Azatricycloundecadienone.

Camphorquinone and its derivatives constitute an important class of organic compounds with pharmacological importance. The most interesting aspects of these compounds are their applications in permanent restorative dental resins ${ }^{(1-3)}$, as substrate in dental cements ${ }^{(4,5)}$, dentin-bonding agents ${ }^{(6,7)}$, and in root canal filling materials ${ }^{(1)}$. In continuation to our work in the field of phosphonium ylides ${ }^{(8-14)}$, the present investigation has aimed to investigate the reaction of camphorquinone and its derivatives, such as, 1,7,7-trimethyl- bicycle [2.2.1]heptane-2,3-dione (1), 3-(2-phenylhydrazono)-1,7,7-trimethylbicyclo [2.2.1]heptan-2-one (13), and 3-(hydroxyimino)-1,7,7-trimethylbicyclo[2.2.1] heptan-2one (16) with the active nucleophilic phosphacumulene reagents, namely ( $\mathrm{N}$ phenyliminovinylidene) -(2a), (2-oxovinylidene) - (2b), and (2-thioxovinylidene) - triphenylphosphorane (2c). These active phosphacumulene ylides are important phosphorus reagents, used for the synthesis of heterocyclic phosphorus compounds ${ }^{(15,16)}$. A comparative study on the behavior of camphorquinone 1 and its derivatives 13, and 16 toward stabilized phosphonium ylides namely, methoxycarbonyl- (6a), and ethoxycarbonyl-methylenetriphenylphosphorane (6b) has been performed, too.

*Correspondent: E-mail: s_maigali@yahoo.com 


\section{Results and Discusion}

We have found that the reaction of camphorquinone (1) with (2) moleequivalents of (N-phenyliminovinylidene) triphenylphosphorane (2a), in tetrahydrofuran at room temperature for $10 \mathrm{hr}$, triphenylphosphine oxide together with the phosphanylidene cyclobutylidene camphorquinone (5a) were obtained. Structural support for compound 5a was based upon spectroscopic data and molecular weight determination (MS). The IR spectrum of $5 \mathrm{a}\left(\mathrm{KBr}, \mathrm{cm}^{-1}\right)$ showed strong absorption bands at $1700(\mathrm{C}=\mathrm{O}), 1577(\mathrm{C}=\mathrm{N})$, and 1463 (P-Phenyl) ${ }^{(17)}$. The ${ }^{1} \mathrm{H}$ NMR spectrum of $5 \mathrm{a}\left(\mathrm{CDCl}_{3}, \delta \mathrm{ppm}\right)$ showed signals at $0.99\left(\mathrm{~s}, 3 \mathrm{H}, \mathrm{CH}_{3}\right)$, $1.03\left(\mathrm{~s}, 6 \mathrm{H}, 2 \mathrm{CH}_{3}\right), 1.25-1.43\left(\mathrm{~m}, 2 \mathrm{H}, \mathrm{CH}_{2}\right), 1.62-1.86\left(\mathrm{~m}, 2 \mathrm{H}, \mathrm{CH}_{2}\right), 2.33(\mathrm{~m}, \mathrm{H}$, $\mathrm{CH}$ ), and 7.32-7.93 (m, 25H, aromatics). Its ${ }^{13} \mathrm{C} \mathrm{NMR} \mathrm{spectrum}\left(\mathrm{CDCl}_{3}, \delta \mathrm{ppm}\right)$ showed signals at $18.32\left(\mathrm{CH}_{3}\right), 19.91\left(2 \mathrm{CH}_{3}\right), 26.95,29.96\left(2 \mathrm{CH}_{2}\right), 39.75,(\mathrm{CH})$, $46.03\left(\underline{\mathrm{C}}-\left(\mathrm{CH}_{3}\right)_{2}\right), 49.25\left(\underline{\mathrm{C}}-\mathrm{CH}_{3}\right), 133.25(\mathrm{C}=\mathrm{P}), 169.55(\mathrm{C}=\mathrm{N})$, and 205.33 $(\mathrm{C}=\mathrm{O})$. A signal at $\delta=15.5 \mathrm{ppm}$ was observed in its ${ }^{31} \mathrm{P}$ NMR which fits with the phosphorane on a four -membered ring ${ }^{(18,19)}$. In the MS of $5 \mathrm{a}$ an ion peak at $\mathrm{m} / \mathrm{z}$ $=\left[262\left(\mathrm{PPh}_{3}\right) 100 \%\right]$ was observed. Moreover, the reaction of compound 1 with 2 moles of phosphacumulenes ( $2 b$ and $2 c$ ) proceeded in dry toluene under reflux for $12 \mathrm{hr}$ in case of $2 \mathrm{~b}, 14 \mathrm{hr}$ with $2 \mathrm{c}$, to give triphenylphosphine oxide together with $5 \mathrm{~b}$ or $5 \mathrm{c}$. Compounds $5 \mathrm{a}-5 \mathrm{c}$ were equally obtained, irrespective whether 2 or 4 mole equivalents of the phosphacumulenes $(2 \mathrm{a}-2 \mathrm{c})$ were used. Formation of compounds $5 a-5$ c occurs by the [2+2] -cycloaddition of one carbonyl group in the camphorquinone (1) to the ylidic C-P of the phosphacumulenes (2) to give the oxaphosphetanes (3) as intermediates (20-22). Triphenylphosphine oxide was eliminated with the formation of the unstable ketenes (4), ${ }^{(23)}$ which add a second molecule of the active ylides (2) by a [2+2] cycloaddition to give phosphanylidenecyclobutylidene camphorquiones (5a-5c) (Scheme1).

When camphorquinonephenylhydrazone (13) was treated with (N-phenyliminovinylidene) -(2a) or (2-oxovinylidene)-triphenylphosphorane (2b) in dry THF and refluxed for $10 \mathrm{hr}$ in the case of $2 \mathrm{a}, 14 \mathrm{hr}$ when $2 \mathrm{~b}$ was used, the yellow adducts (14a and b) were isolated in good yields. Compounds 14a and 14b were obtained in the same yields irrespective whether 1 or 2 mole equivalents of the phosphacumulenes (2) were used. Molecular weight determinations (MS) and spectroscopic results were consistent with the assigned structures of compounds $14 \mathrm{a}$ and $14 \mathrm{~b}$. The IR spectrum of the phosphorane $(14 \mathrm{a})\left(\mathrm{KBr}, \mathrm{cm}^{-1}\right)$ revealed the absence of absorption band for $(\mathrm{C}=\mathrm{N})$ group of hydrazone (13) and showed the presence of strong absorption bands at $v=3257(\mathrm{NH}), 1702(\mathrm{C}=\mathrm{O}), 1625(\mathrm{C}=\mathrm{N}$, ylide), and $1448 \mathrm{~cm}^{-1}$ (P-Phenyl). The ${ }^{1} \mathrm{H}$ NMR spectrum of 14a (DMSO, $\delta \mathrm{ppm}$ ) showed signals at $0.98\left(\mathrm{~s}, 3 \mathrm{H}, \mathrm{CH}_{3}\right), 1.11\left(\mathrm{~s}, 6 \mathrm{H}, 2 \mathrm{CH}_{3}\right), 1.22-1.40(\mathrm{~m}, 2 \mathrm{H}$, $\mathrm{CH}_{2}$ ), 1.50-1.65 (m, 2H, $\left.\mathrm{CH}_{2}\right), 2.53(\mathrm{~m}, \mathrm{H}, \mathrm{CH}), 7.13-7.38$ (m, 25H, aromatic), and the $(\mathrm{NH})$ proton resonated at $\delta=11.53$ (exchangeable with $\mathrm{D}_{2} \mathrm{O}$ ) ppm. In its ${ }^{13} \mathrm{C}$ NMR spectrum (DMSO, $\delta \mathrm{ppm}$ ), signals were recoded at $17.48\left(\mathrm{CH}_{3}\right)$, $20.62\left(2 \mathrm{CH}_{3}\right), 22.16,30.13\left(2 \mathrm{CH}_{2}\right), 39.97(\mathrm{CH}), 46.73\left(\underline{\mathrm{C}}-\left(\mathrm{CH}_{3}\right)_{2}\right), 49.88(\underline{\mathrm{C}}-$ $\left.\mathrm{CH}_{3}\right), 143.54(\mathrm{C}=\mathrm{P}), 156.65(\mathrm{C}=\mathrm{N})$, and $202.83(\mathrm{C}=\mathrm{O})$. The ${ }^{31} \mathrm{P} \mathrm{NMR}$

Egypt. J. Chem. 53, No. 2 (2010) 
shift was recorded for $14 \mathrm{a}$ at $\delta=19.37 \mathrm{ppm}$. Its mass spectrum indicated the presence of ion peak at $\mathrm{m} / \mathrm{z}=$ [256 camphorquinonephenylhydrazone, $13.86 \%$, which originate via the cleavage of the molecular ion peak at $\mathrm{m} / \mathrm{z}=633\left[\mathrm{M}^{+}\right]$. Compounds $14 \mathrm{a}$ and $14 \mathrm{~b}$ were formed via the addition of phosphacumulenes (2a or $2 \mathrm{~b}$ ) to the phenylhydrazone $\mathrm{C}=\mathrm{N}$ group rather than the $(\mathrm{NH})$ or carbonyl group of phenylhydrazone of the starting material 13 (Scheme 2).

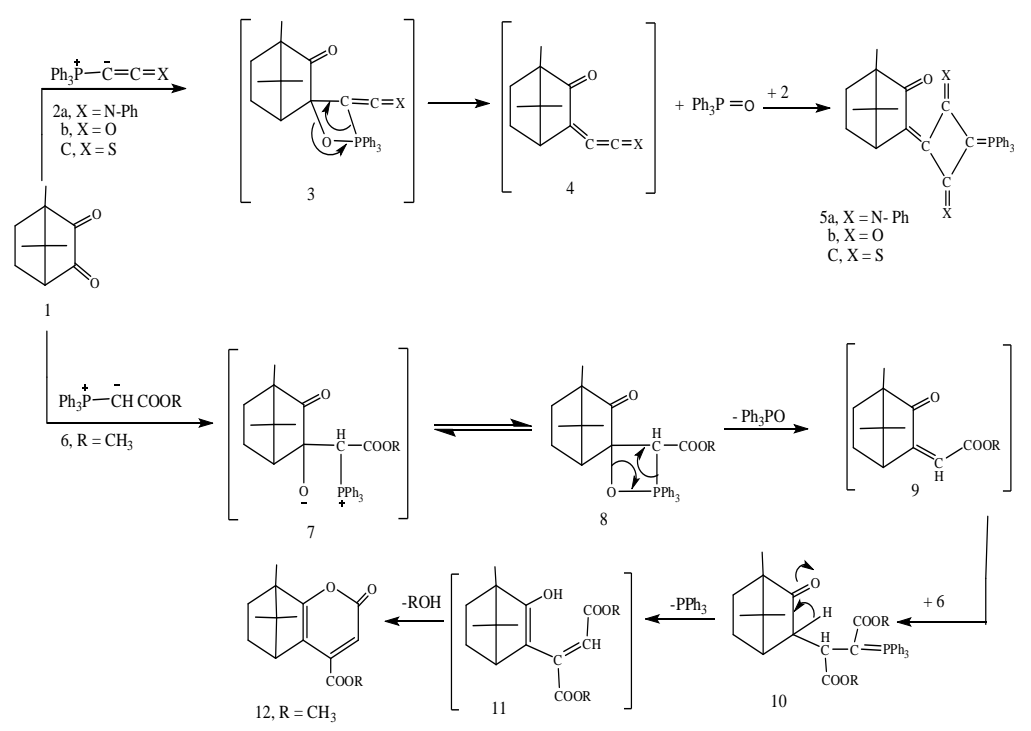

Scheme 1

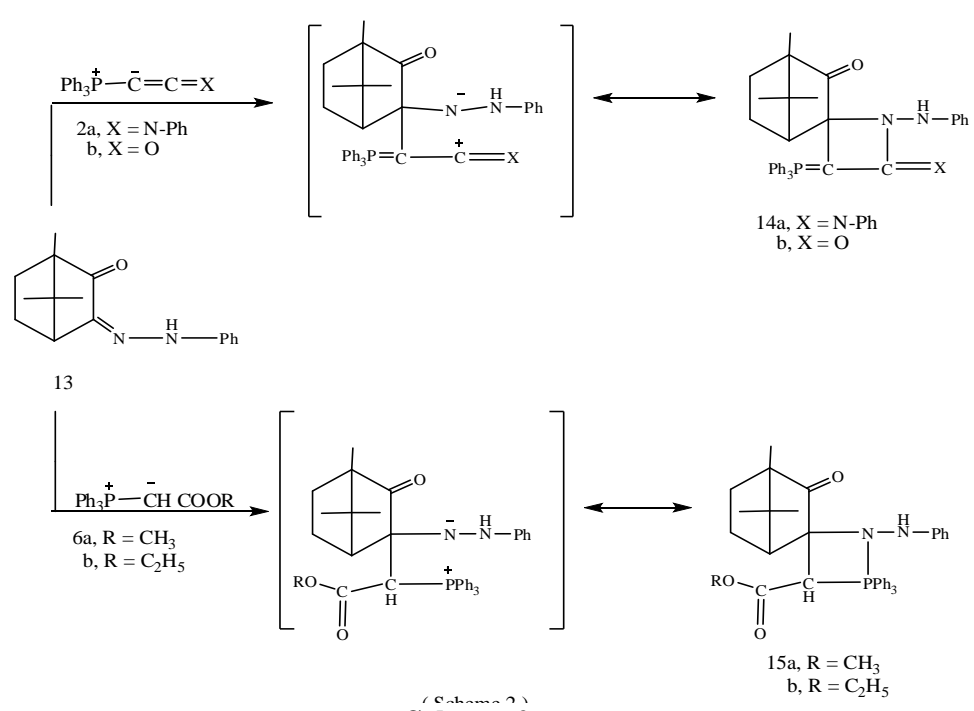

Scheme 2 
When camphorquinone oxime (16) was reacted with phosphacumulene ylides ( $2 \mathrm{a}$ or $2 \mathrm{~b}$ ) in 1:1 molar ratio in dry boiling toluene for $8 \mathrm{hr}$ in case of $2 \mathrm{a}$ and $12 \mathrm{hr}$ in case of $2 b$, to give the corresponding phosphoranes (17a and 17b). Structural assignments for $17 \mathrm{a}$ and $\mathrm{b}$ were supported by spectroscopic data. The IR spectum of $17 \mathrm{a}\left(\mathrm{KBr}, \mathrm{cm}^{-1}\right)$ confirmed the proposed structure showing no absorption band for the $=\mathrm{N}-\mathrm{OH}$ group, and revealed the presence of strong absorption bands at v1706 $(\mathrm{C}=\mathrm{O}), 1682,1648(2 \mathrm{C}=\mathrm{N})$, and 1485 (P-Phenyl). Its ${ }^{1} \mathrm{H}$ NMR spectrum $\left(\mathrm{CDCl}_{3}, \delta \mathrm{ppm}\right)$ displayed signals at $0.99\left(\mathrm{~s}, 3 \mathrm{H}, \mathrm{CH}_{3}\right), 1.01\left(\mathrm{~s}, 6 \mathrm{H}, 2 \mathrm{CH}_{3}\right), 1.38$ $1.63\left(\mathrm{~m}, 2 \mathrm{H}, \mathrm{CH}_{2}\right), 1.69-1.89\left(\mathrm{~m}, 2 \mathrm{H}, \mathrm{CH}_{2}\right), 2.53(\mathrm{~m}, \mathrm{H}, \mathrm{CH}), 4.24(\mathrm{~d}, \mathrm{H}, \mathrm{CH}=\mathrm{P}$, $\left.{ }^{2} \mathrm{~J}_{\mathrm{HP}}=24.15 \mathrm{~Hz}\right)$, and 7.15-7.42 (m, 20H, aromatic), whereas its ${ }^{13} \mathrm{C} \mathrm{NMR}$ spectrum $\left(\mathrm{CDCl}_{3}, \delta \mathrm{ppm}\right)$ revealed the presence of signals at $18.07\left(\mathrm{CH}_{3}\right), 20.63$ $\left(2 \mathrm{CH}_{3}\right), 22.77,29.77\left(2 \mathrm{CH}_{2}\right), 39.54(\mathrm{CH}), 44.52\left(\underline{\mathrm{C}}-\left(\mathrm{CH}_{3}\right)_{2}\right), 48.30\left(\underline{\mathrm{C}}-\left(\mathrm{CH}_{3}\right)\right.$, $139.37(\mathrm{C}=\mathrm{P}), 154.21,158.45(2 \mathrm{C}=\mathrm{N})$, and $201.01(\mathrm{C}=\mathrm{O})$. The ${ }^{31} \mathrm{P} \mathrm{NMR}$ shift recorded for $17 \mathrm{a}$ was at $\delta=-19.54 \mathrm{ppm}$. The MS of $17 \mathrm{a}$ was found at $\mathrm{m} / \mathrm{z}=[283$ $\left(\mathrm{M}^{+}-\left(\mathrm{CH}=\mathrm{PPh}_{3}\right) 10.95 \%\right.$, and $\left.278\left(\mathrm{Ph}_{3} \mathrm{PO}\right) 62.02 \%\right]$. Formation of compounds $17 \mathrm{a}$ and $17 \mathrm{~b}$ occurs via the addition of phosphacumulenes ( $2 \mathrm{a}$ or $2 \mathrm{~b}$ ) to the $\mathrm{OH}$ group rather than the carbonyl group of oxime (16) (Scheme 3).

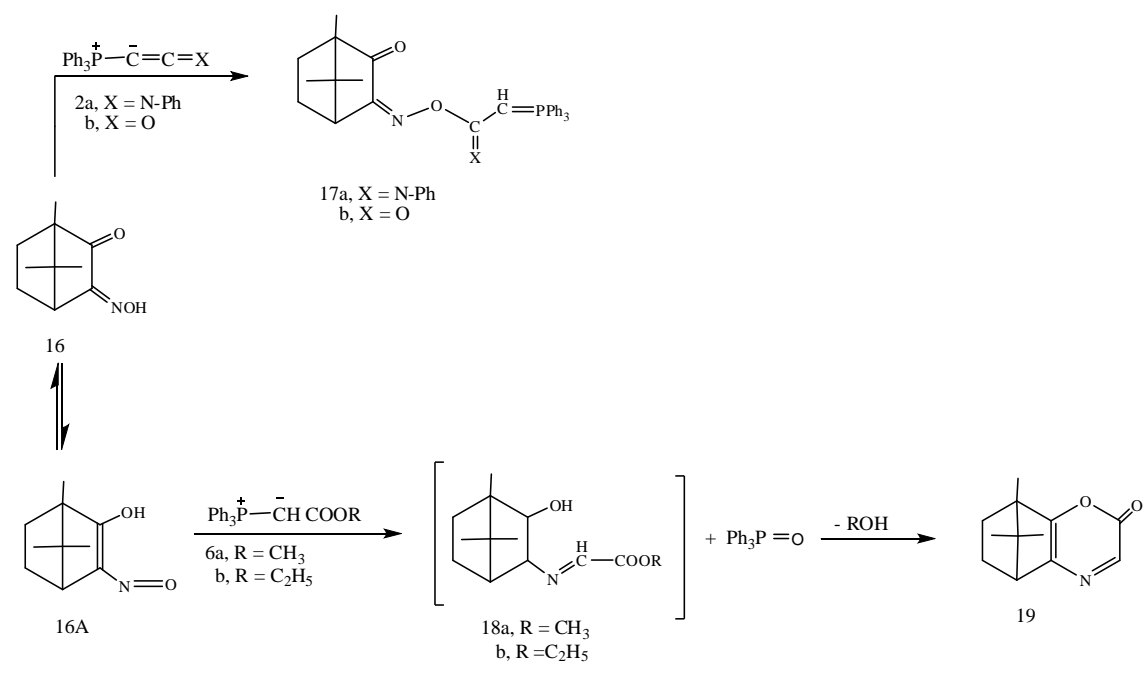

Scheme 3

The behavior of the stabilized phosphonium ylides (6a and $6 \mathrm{~b}$ ) towards camphorquinone 1 and its derivatives 13, and 16 was also studied to determine the site of attack. We have found that the stabilized phosphonium ylide, namely methoxycarbonylmethylenetriphenylphosphorane (6) reacted with camphorquinone (1), in dry toluene under reflux for $8 \mathrm{hr}$ to give yellow three adducts 8,10 and 12 , respectively, alongwith triphenylphosphine, and triphenylphosphine oxide. Compounds 8,10 , and 12 were equally obtained whether 1 mole equivalent or 2 mole- equivalents of Wittig reagent 6 were used with respect to 1 mole equivalent of compound 1 . The structures of compounds 8,10 , and 12 were

Egypt. J. Chem. 53, No. 2 (2010) 
based on spectroscopic data and molecular weight determination (MS), which agreed with the proposed structures. The IR spectrum of $8\left(\mathrm{KBr}, \mathrm{cm}^{-1}\right)$ showed strong absorption bands at 1727 (br, $\mathrm{C}=\mathrm{O}$, cyclic ketone, ester), 1451 (P-Phenyl), and 1120 due to an aromatic vibration involving some $\mathrm{P}-\mathrm{C}$ stretching. The ${ }^{1} \mathrm{HNMR}$ spectrum $\left(\mathrm{CDCl}_{3}, \delta \mathrm{ppm}\right)$ of 8 , showed singals at $0.99\left(\mathrm{~s}, 3 \mathrm{H}, \mathrm{CH}_{3}\right)$, $1.11\left(\mathrm{~s}, 6 \mathrm{H}, 2 \mathrm{CH}_{3}\right), 1.37-1.68\left(\mathrm{~m}, 2 \mathrm{H}, \mathrm{CH}_{2}\right), 2.06-2.18\left(\mathrm{~m}, 2 \mathrm{H}, \mathrm{CH}_{2}\right), 2.29(\mathrm{~m}$, $\mathrm{H}, \mathrm{CH})$, a doublet was observed at $\delta=3.00\left(\mathrm{~d}, 1 \mathrm{H}, \mathrm{CH}-\mathrm{P},{ }^{2} \mathrm{~J}_{\mathrm{HP}}=23.60 \mathrm{~Hz}\right), 3.72$ $\left(\mathrm{s}, 3 \mathrm{H}, \mathrm{OCH}_{3}\right)$, and $7.06-7.12\left(\mathrm{~m}, 15 \mathrm{H}\right.$, aromatic). The ${ }^{13} \mathrm{C}$ NMR spectrum of 8 $\left(\mathrm{CDCl}_{3}, \delta \mathrm{ppm}\right)$ showed signals at $17.72\left(\mathrm{CH}_{3}\right), 20.70\left(2 \mathrm{CH}_{3}\right), 25.81,29.92$ $\left(2 \mathrm{CH}_{2}\right), 39.95(\mathrm{CH}), 45.32\left(\underline{\mathrm{C}}-\left(\mathrm{CH}_{3}\right)_{2}\right), 49.48\left(\underline{\mathrm{C}}-\mathrm{CH}_{3}\right), 57.23\left(\mathrm{OCH}_{3}\right), 118.12(\mathrm{C}-$ $\mathrm{P}), 166.65(\mathrm{C}=\mathrm{O}$, ester), and $207.03(\mathrm{C}=\mathrm{O}$, cyclic ketone). A signal at $\delta=30.71$ ppm was observed in the ${ }^{31} \mathrm{P}$ NMR spectrum of 8 which fits with the phosphorane ${ }^{(24)}$. In the MS of 8 ion peaks were observed at $\mathrm{m} / \mathrm{z}=222\left[\left(\mathrm{M}^{+}-\right.\right.$ $\left.\mathrm{Ph}_{3} \mathrm{PO}\right) 61.02 \%$, and $278\left(\mathrm{Ph}_{3} \mathrm{PO}\right) 13.11 \%$ ]. Compound 10 is quite stable, its structure was established from spectroscopic data. The IR spectrum of $10(\mathrm{KBr}$, $\left.\mathrm{cm}^{-1}\right)$ exhibited absorption bands at $=1733(\mathrm{C}=\mathrm{O}$, camphor $), 1662 \quad(\mathrm{br}, \mathrm{C}=\mathrm{O}$, ester), and 1448 (P-Phenyl). The ${ }^{1} \mathrm{H}$ NMR spectrum $\left(\mathrm{CDCl}_{3}, \delta \mathrm{ppm}\right)$ of 10 revealed the presence of signals at $0.98\left(\mathrm{~s}, 3 \mathrm{H}, \mathrm{CH}_{3}\right), 1.12\left(\mathrm{~s}, 6 \mathrm{H}, 2 \mathrm{CH}_{3}\right), 1.46$ $1.65\left(\mathrm{~m}, 2 \mathrm{H}, \mathrm{CH}_{2}\right), 1.86-1.99\left(\mathrm{~m}, 2 \mathrm{H}, \mathrm{CH}_{2}\right), 2.51$ (m, H, CH), 2.54 (dd, $\mathrm{CH}-\mathrm{CH}-$ $\left.\mathrm{COOCH}_{3},{ }^{3} \mathrm{~J}_{\mathrm{HH}}=11.45 \mathrm{~Hz},{ }^{4} \mathrm{~J}_{\mathrm{HP}}=4.2 \mathrm{~Hz}\right)$ and $2.76(\mathrm{dd}, \mathrm{CH}-\mathrm{C}=\mathrm{P}$, methine, ${ }^{3} \mathrm{~J}_{\mathrm{HH}}=11.45 \mathrm{~Hz},{ }^{3} \mathrm{~J}_{\mathrm{HP}}=12.55 \mathrm{~Hz}$ ). Moreover, two singlets were found at $\delta=3.70$, $3.74 \mathrm{ppm}$ due to the presence of two methoxy groups of the ester, and the aromatic protons appeared as multiplets in the region $\delta=7.01-7.19 \mathrm{ppm}$ which integrated to 15 protons. The ${ }^{13} \mathrm{C}$ NMR spectrum of $10\left(\mathrm{CDCl}_{3}, \delta \mathrm{ppm}\right)$, showed signals at $17.93\left(\mathrm{CH}_{3}\right), 20.82(\mathrm{H}-\mathrm{C}-\mathrm{C}=\mathrm{P}), 21.24\left(2 \mathrm{CH}_{3}\right), 26.82,29.49\left(2 \mathrm{CH}_{2}\right)$ $39.38\left(\mathrm{CH}\right.$, cyclic ketone), $45.63\left(\underline{\mathrm{C}}-\left(\mathrm{CH}_{3}\right)_{2}\right), 47.56\left(\underline{\mathrm{CH}},-\mathrm{CH}-\mathrm{COOCH}_{3}\right), 51.88$ $\left(\underline{\mathrm{C}}-\mathrm{CH}_{3}\right), 58.22,58.81\left(2 \mathrm{OCH}_{3}\right), 148.95(\mathrm{C}=\mathrm{P}), 166.42,168.23(2 \mathrm{C}=\mathrm{O}$, ester $)$, and $204.49(\mathrm{C}=\mathrm{O}$, camphor). In the mass spectrum of 10 ion peaks at $\mathrm{m} / \mathrm{z}=$ [279 $\left(\mathrm{M}^{+}-\left(\mathrm{Ph}_{3} \mathrm{PO}\right) 6.21 \%, 262\left(\mathrm{PPh}_{3}\right) 3.84 \%\right]$ were found. Moreover, a signal at $\delta=31.03$ ppm was observed in its ${ }^{31} \mathrm{P}$ NMR spectrum. The identity of compound 12 was supported by molecular weight determination (MS) as well as spectroscopic data, which are compatible with the assigned structure. The IR spectrum of $12\left(\mathrm{KBr}, \mathrm{cm}^{-1}\right)$ disclosed the presence of strong absorption bands at $1667(\mathrm{C}=\mathrm{O}$, lactone $)$, and $1662 \mathrm{~cm}^{-1}(\mathrm{C}=\mathrm{O}$, ester $)$. The ${ }^{1} \mathrm{H}$ NMR spectrum of $12\left(\mathrm{CDCl}_{3}, \delta \mathrm{ppm}\right)$ showed signals at $1.11\left(\mathrm{~s}, 3 \mathrm{H}, \mathrm{CH}_{3}\right), 1.26\left(\mathrm{~s}, 6 \mathrm{H}, 2 \mathrm{CH}_{3}\right)$, 1.35-1.58 (m, 2H, $\left.\mathrm{CH}_{2}\right), 1.62-1.83\left(\mathrm{~m}, 2 \mathrm{H}, \mathrm{CH}_{2}\right), 2.25(\mathrm{~m}, \mathrm{H}, \mathrm{CH}), 3.73(\mathrm{~s}, 3 \mathrm{H}$, $\left.\mathrm{OCH}_{3}\right)$, and $5.14\left(\mathrm{~s}, \mathrm{H}, \mathrm{CH}\right.$, aromatic). The ${ }^{13} \mathrm{C} \mathrm{NMR}$ spectrum of $12\left(\mathrm{CDCl}_{3}, \delta\right.$ ppm) showed signals at $14.28\left(\mathrm{CH}_{3}\right), 21.56\left(2 \mathrm{CH}_{3}\right), 26.67,31.20\left(2 \mathrm{CH}_{2}\right), 39.21$ $(\mathrm{CH}$, camphor $), 46.82\left(\underline{\mathrm{C}}-\left(\mathrm{CH}_{3}\right)_{2}\right), 48.95\left(\underline{\mathrm{C}}-\mathrm{CH}_{3}\right), 56.12\left(\mathrm{OCH}_{3}\right), 123.55(\mathrm{CH}$, aromatic), $163.76(\mathrm{C}=\mathrm{O}$, lactone), and $169.45(\mathrm{C}=\mathrm{O}$, ester) ppm. Its mass spectrum showed an ion peak at the $\mathrm{m} / \mathrm{z}=[263(\mathrm{M}+\mathrm{H}) 7.03 \%]$. The reaction of Witting reagent (6a) with camphorquinone (1) is explained by the nucleophilic addition of phosphonium ylide 6 a to one of the carbonyl groups of 1 to give the betaine (7), which is cyclized to the oxaphosphetane (8). Part of 8 decomposed to give the alkene (9) together with triphenylphosphine oxide. Addition of a second molecule of the stable ylide (6) to the alkene (9) to afford the phosphonium ylide 
(10). Expulsion of triphenylphosphine from the intermediate betaine 10 gives the intermediate 11, which is cyclized via elimination of methanol to form camphorquinone derivative 12 (Scheme 1).

When camphorquinonephenylhydrazone (13) was treated with the stabilized phosphonium ylides 6 , in dry boiling toluene for $10 \mathrm{hr}$ in case of $6 \mathrm{a}$ and $12 \mathrm{hr}$. when $6 \mathrm{~b}$ was used. The adducts $(15 \mathrm{a}$ and $15 \mathrm{~b})$ were obtained in good yields. The structures of compounds $15 \mathrm{a}$ and $15 \mathrm{~b}$ were assigned from their spectral data. The IR spectrum of $15 \mathrm{a}\left(\mathrm{KBr}, \mathrm{cm}^{-1}\right)$ showed bands at $=$ $3264(\mathrm{NH}), 1695$ (br, C=O, alicyclic carbonyl, and ester), and $1509 \mathrm{~cm}^{-1}$ (PPhenyl). The ${ }^{1} \mathrm{H}$ NMR spectrum of $15 \mathrm{a}\left(\mathrm{CDCl}_{3}, \delta \mathrm{ppm}\right)$ showed signals at $1.02\left(\mathrm{~s}, 3 \mathrm{H}, \mathrm{CH}_{3}\right), 1.15\left(\mathrm{~s}, 6 \mathrm{H}, 2 \mathrm{CH}_{3}\right), 1.34-1.50\left(\mathrm{~m}, 2 \mathrm{H}, \mathrm{CH}_{2}\right), 1.56-1.64(\mathrm{~m}$, $\left.2 \mathrm{H}, \mathrm{CH}_{2}\right), 2.31(\mathrm{~m}, \mathrm{H}, \mathrm{CH}), 3.12\left(\mathrm{~d}, \mathrm{H}, \mathrm{CH}-\mathrm{P},{ }^{2} \mathrm{~J}_{\mathrm{HP}}=22.45 \mathrm{~Hz}\right), 3.62(\mathrm{~s}, 3 \mathrm{H}$, $\left.\mathrm{OCH}_{3}\right), 7.44-7.74(\mathrm{~m}, 20 \mathrm{H}$, aromatics $)$, and $11.87 \mathrm{ppm}(\mathrm{s}, \mathrm{H}, \mathrm{NH}$, exchangeable with $\left.\mathrm{D}_{2} \mathrm{O}\right)$. Its ${ }^{13} \mathrm{C}$ NMR showed $\left(\mathrm{CDCl}_{3}, \delta \mathrm{ppm}\right)$ signals at $18.23\left(\mathrm{CH}_{3}\right), 21.67\left(2 \mathrm{CH}_{3}\right), 24.17,30.35\left(2 \mathrm{CH}_{2}\right), 38.56(\mathrm{CH}$, alicyclic $)$, $43.45\left(\underline{\mathrm{C}}-\left(\mathrm{CH}_{3}\right)_{2}\right), 46.3\left(\underline{\mathrm{C}}-\mathrm{CH}_{3}\right), 57.99\left(\mathrm{OCH}_{3}\right), 114.76(\mathrm{CH}-\mathrm{P}), 169.9(\mathrm{C}=\mathrm{O}$, ester), and $204.60 \mathrm{ppm}\left(\mathrm{C}=\mathrm{O}\right.$, alicyclic carbonyl). In the ${ }^{31} \mathrm{P}$ NMR spectrum of $15 \mathrm{a}$ a signal at $\delta=26.34 \mathrm{ppm}$ was observed. The mass spectrum of $5 \mathrm{a}$ showed ion peaks at $\mathrm{m} / \mathrm{z}=\left[592\left(\mathrm{M}^{+2}\right) 11.10 \%, 278\left(\mathrm{Ph}_{3} \mathrm{PO}\right) 19.01 \%\right)$, and 256(substrate 13) 52.12\%)]. Formation of compounds 15 occurred due to nucleophilic attack by the carbanion centre of the phosphoranes (6) preferentially at the electron deficient carbon-nitrogen double bond, rather than the $(\mathrm{NH})$ or carbonyl group of the bifunctional camphorquinonephenylhydrazone (13), even we used 2 mole of the phosphoranes (6), to give compounds 15 (Scheme 2).

Moreover, the reaction of camphorquinone oxime (16) with alkoxyphosphoranes (6a and 6b) was investigated. Compound 16 reacted in equimolar ratio in dry boiling toluene for $8 \mathrm{hr}$, to give one and the same product 19 alongwith triphenylphosphine oxide. The structure of compound 19 is corroborated by the frequency of the $\mathrm{C}=\mathrm{O}$ band in the IR spectrum at $1665 \mathrm{~cm}^{-1}$ and absence of the $=\mathrm{N}-\mathrm{OH}$ group absorption. In its ${ }^{1} \mathrm{H}$ NMR spectrum $\left(\mathrm{CDCl}_{3}, \delta \mathrm{ppm}\right)$ the following singals were observed at $1.01(\mathrm{~s}, 3 \mathrm{H}$, $\left.\mathrm{CH}_{3}\right), 1.26\left(\mathrm{~s}, 6 \mathrm{H}, 2 \mathrm{CH}_{3}\right), 1.39-1.59\left(\mathrm{~m}, 2 \mathrm{H}, \mathrm{CH}_{2}\right), 1.65-1.74\left(\mathrm{~m}, 2 \mathrm{H}, \mathrm{CH}_{2}\right)$, $2.53(\mathrm{~m}, \mathrm{H}, \mathrm{CH})$ and $5.10(\mathrm{~s}, \mathrm{H}, \mathrm{CH}$, aromatic). In the MS of 19 an ion peak was observed at $\mathrm{m} / \mathrm{z}=205\left[\left(\mathrm{M}^{+}\right) 30.54 \%\right]$. Reaction of the bifunctional diketone monoxime (16) with phosphonium ylides (6) proceedes via oxime $\mathrm{OH}$ group which is transformed firstly to the nitroso-compound 16A due to the migration of the oxime proton to the electron rich centre of the molecule. The nitroso-compound reacts with ylides 6 to form the reactive intermediates 18 and triphenylphosphine oxide. Compounds 18 are cyclized via elimination of an alcohol molecule to produce the final product (19) (Scheme 3).

Egypt. J. Chem. 53, No. 2 (2010) 


\section{Conclusion}

From the above results, it could be concluded that the reaction of the active phosphacumulenes and the stabilized phosphonium ylides with camphorquinone and its monohydrazone and monooxime derivative represents a new approach to the construction of new heterocycles. Moreover, the reaction of camphorquinone with the phosphonium reagents takes place only at the carbonyl goup in position 3 and not that in position 2. This is due to the hindred nature ${ }^{(25)}$ of camphorquinone carbonyl at position 3 even when excess of the phosphorus reagents is used. Furthermore, no shift for the $\mathrm{CH}_{3}$ group in position 1 to up field absorption was observed in the ${ }^{1} \mathrm{H}$ NMR spectra of the reaction products. This confirms attack by the phosphorus reagents on the carbonyl group at position 3. The difference in the nucleophilic character and reactivity of the phosphacumulenes $5 \mathrm{a}>5 \mathrm{~b}>5 \mathrm{c}$ is also demonstrated in this study. Therefore, it is safe to state that the reaction courses of active phosphacumulenes and stabilized phosphonium ylides with substrates 1,13 and 16 are rather dependent on the nature of the reactants and the reaction temperature. These processes can be considered as new and simple routes for the preparation of different ring systems, which can not be obtained by other conventional methods.

\section{Experimental}

All melting points were measured on a Gallenkamp electrothermal digital melting point apparatus. Elemental analytical data were obtained at the analytical laboratory of the National Reseach Centre. Satisfactory elemental analyses results agreed with the calculated values. The infrared spectra were recorded in $\mathrm{KBr}$ disks on a Jasco Fourier Transform Infrared Spectrophotometer model FT/IR-3000E. The ${ }^{1} \mathrm{H}$ NMR spectra were recorded in deuterated $\mathrm{CDCl}_{3}$ or DMSO on JEOL JNM-EX 270 (at $270 \mathrm{MHz}$ ) and /or JEOL 500 AS (at 500 $\mathrm{MHz}$ ) Spectrometer using TMS as an internal reference. ${ }^{13} \mathrm{C}$ NMR spectra were recorded on JEOL500 AS (at $125 \mathrm{MHz}$ ). ${ }^{31} \mathrm{P}$ NMR spectra were run on the same spectrometer using $\mathrm{H}_{3} \mathrm{PO}_{4}(85 \%)$ as an external reference. Mass spectra (EI-MS) were recorded at 70 e V on a Finnigan MAT SSQ 7000 Spectrometer. The reported yields are used upon pure materials isolated by column chromatogrphy on silica gel 60 (Merck).

Reaction of camphorquinone (1) with active phosphacumulene ylides (2a-c) Preparation of 3- [2,4-Diphenylimino -3- (triphenyl - $\lambda^{5}$ - phosphanylidene) cyclobutylide-ene]-4,7,7-trimethyl bicyclo[2.2.1]heptan-2-one (5a).

To a solution of camphorquinone (1) $(0.16 \mathrm{~g}, 0.001 \mathrm{~mol})$ in dry THF, was added dropwise with stirring at $\mathrm{rt}$ a solution of ( $\mathrm{N}$-phenyliminovinylidene) triphenylphosphorane $(2 \mathrm{a})^{(26)}(0.75 \mathrm{~g}, 0.002 \mathrm{~mol})$ in $30 \mathrm{ml}$ of THF. The reaction mixture was stirred for $10 \mathrm{hr}$. THF was distilled off under reduced pressure, the residue was chromatographed on silica gel using pet.ether / ethyl acetate as an eluent $(7: 3, v / v)$, to give $5 \mathrm{a}$, as yellow crystals $\mathrm{mp}=256^{\circ} \mathrm{C}(66 \%)$, and triphenylphosphine oxide was isolated, too, $\left(\mathrm{mp}\right.$, mixed $\mathrm{mp}=151^{\circ} \mathrm{C}$. $^{(27)}$ 
$\left[\mathrm{C}_{44} \mathrm{H}_{39} \mathrm{~N}_{2} \mathrm{OP}, 642.77\right] . \mathrm{C}, 82.22 ; \mathrm{H}, 6.12 ; \mathrm{N}, 4.36 ; \mathrm{P}, 4.82$. Found: $\mathrm{C}, 82.12 ; \mathrm{H}$, $6.10 ; \mathrm{N}, 4.16 ; \mathrm{P}, 4.53$.

Reaction of Compound 1 with Active Phosphacumulenes $2 b$ and $c$

To a solution of compound $1(0.16 \mathrm{~g}, 0.001 \mathrm{~mol})$ in $20 \mathrm{ml}$ of dry toluene, was added a solution of (2-oxovinylidene) - $(2 \mathrm{~b})^{(28)}(0.60 \mathrm{~g}, 0.002 \mathrm{~mol})$, or (2thioxovinylidene)-triphenyl- phosphorane $(2 \mathrm{c})^{(28)}(0.63 \mathrm{~g}, 0.002 \mathrm{~mol})$ in $30 \mathrm{ml}$ of dry toluene. The reaction mixture was refluxed for $12 \mathrm{hr}$ when $2 \mathrm{~b}$ was used, and for $14 \mathrm{hr}$ in case of $2 \mathrm{c}$. After the solvent has been $5 \mathrm{~b}$ or $5 \mathrm{c}$ together with triphenylphosphine oxide.

3-[2,4-Dioxo-3- (triphenyl- $\lambda^{5}$ - phosphanylidene) cyclobutylidene] -4,7,7 trimethylbicyclo [2.2.1] heptan-2-one (5b).

Eluent: $\mathrm{n}$-hexane / acetone $(8: 2, \mathrm{v} / \mathrm{v})$ was isolated as yellow crystals, $\mathrm{m} \mathrm{p}=$ $274^{\circ} \mathrm{C}(63 \%)$. Anal. Calcd for $\left[\mathrm{C}_{32} \mathrm{H}_{29} \mathrm{O}_{3} \mathrm{P}, 492.54\right]$. C, 78.03; H, 5.93; P, 6.29. Found: C, 78.00; H, 5.53; P, 6.13. IR $\left(\mathrm{KBr}, \mathrm{cm}^{-1}\right): 1754(\mathrm{C}=\mathrm{O}$, alicyclic carbonyl), 1719 (C= O, cyclobutanedione), $1644(\mathrm{P}=\mathrm{C})$, and 1437 (P-Phenyl). ${ }^{1} \mathrm{H}$ $\mathrm{NMR}\left(\mathrm{CDCl}_{3}, \delta \mathrm{ppm}\right): 1.13\left(\mathrm{~s}, 3 \mathrm{H}, \mathrm{CH}_{3}\right), 1.28\left(\mathrm{~s}, 6 \mathrm{H}, 2 \mathrm{CH}_{3}\right), 1.35-1.53(\mathrm{~m}, 2 \mathrm{H}$, $\left.\mathrm{CH}_{2}\right), 1.59-1.65\left(\mathrm{~m}, 2 \mathrm{H}, \mathrm{CH}_{2}\right), 2.36(\mathrm{~m}, \mathrm{H}, \mathrm{CH}), 7.65-7.93(\mathrm{~m}, 15 \mathrm{H}$, aromatics) ppm. MS: $\mathrm{m} / \mathrm{z}=\left[302\left(\mathrm{Ph}_{3} \mathrm{P}=\mathrm{C}=\mathrm{C}=\mathrm{O}\right) 12 \%\right.$, and $\left.278\left(\mathrm{Ph}_{3} \mathrm{PO}\right) 9.95 \%\right]$.

3-[2,4-Dithioxo -3- (triphenyl- $\lambda^{5}$ - phosphanylidene) cyclobutylidene]-4,7,7trimethylbicyclo- [2.2.1] heptan-2-one (5c).

Eluent: $\mathrm{n}$-hexane /acetone $(7: 3, v / v)$ it was produced as yellow crystals, $\mathrm{m} \mathrm{p}=$ $235^{\circ} \mathrm{C}(66 \%)$. Anal. Calcd for $\left[\mathrm{C}_{32} \mathrm{H}_{29} \mathrm{OPS}_{2,}\right.$ 524.68]. C, 73.25; H, 5.57; P, 5.90; S, 12.22. Found: C, 73.11; H, 5.21; P, 5.43; S, 12.10. IR (KBr, $\left.\mathrm{cm}^{-1}\right): 1750$ $(\mathrm{C}=\mathrm{O}), 1432$ (P-Phenyl), and $1130 \mathrm{~cm}^{-1}(\mathrm{C}=\mathrm{S}),{ }^{1} \mathrm{H}$ NMR $\left(\mathrm{CDCl}_{3}, \delta \mathrm{ppm}\right): 1.14$ (s, $\left.3 \mathrm{H}, \mathrm{CH}_{3}\right), 1.28\left(\mathrm{~s}, 6 \mathrm{H}, 2 \mathrm{CH}_{3}\right), 1.37-1.64\left(\mathrm{~m}, 2 \mathrm{H}, \mathrm{CH}_{2}\right), 1.69-1.84(\mathrm{~m}, 2 \mathrm{H}$, $\left.\mathrm{CH}_{2}\right), 2.31(\mathrm{~m}, \mathrm{H}, \mathrm{CH}), 7.64-7.83 \mathrm{ppm}\left(\mathrm{m}, 15 \mathrm{H}\right.$, aromatics). MS: $\mathrm{m} / \mathrm{z}=262\left[\mathrm{M}^{+}-\right.$ $\left(\mathrm{PPh}_{3}\right) 42.83 \%$, and $\left.278\left(\mathrm{Ph}_{3} \mathrm{PO}\right) 100 \%\right]$.

When the reaction of camphorquinone (1) and active phosphacumulenes 2(a-c) was carried out in (1:4 molar ratio), the same products $5(\mathrm{a}-\mathrm{c})$ and triphenylphosphine oxide were produced.

Reaction of 3-(2-phenylhydrazono)-1,7,7-trimethylbicyclo[2.2.1]heptan-2-one (13) with active phosphacumulenes ( $2 a$ and $b)$.

Camphorquinonephenylhydrazone (13) $(0.26 \mathrm{~g}, 0.001 \mathrm{~mol})$ was added dropwise to a solution of phosphacumulenes (2a) $(0.37 \mathrm{~g}, 0.001 \mathrm{~mol})$ or $2 \mathrm{~b}$ $(0.30 \mathrm{~g}, 0.001)$ in dry THF $(30 \mathrm{ml})$, and the reaction mixture was refluxed for $10 \mathrm{hr}$ in case of $2 \mathrm{a}$ and $14 \mathrm{hr}$ when $2 \mathrm{~b}$ was used. The solvent was distilled off under reduced pressure, and the residue was applied to silica gel column chromatography to give $14 \mathrm{a}$, and $14 \mathrm{~b}$, respectively. 
(4,7,7 Trimethyl)-1- (methylamino) -4- (phenylamino) -3- (triphenyl-15phosphoranylidene)- 3-H-spiro[azetidine-2,2-bicyclo[2.2.1] heptane]-3-one (14a).

Eluent: acetone / pet.ether $60-80^{\circ} \mathrm{C}(2: 8, v / v)$, as yellow crystals, $\mathrm{m} \mathrm{p}=130$ ${ }^{\circ} \mathrm{C}(65 \%)$. Anal. Calcd for $\left[\mathrm{C}_{42} \mathrm{H}_{40} \mathrm{~N}_{3} \mathrm{OP}, 633.76\right]$. C, 79.60; H, 6.36; N, 6.63; P, 4.89. Found: C, 79.43; H, 6.12; N, 6.36; P, 4.55.

4,7,7-Trimethyl)-1- (phenylamino)-3- (triphenyl -15-phosphoranylidene)-3H,4H-spiro[aze-tidine-2,2-bicyclo[2.2.1]heptane]-3-4-dione (14b).

Eluent: acetone / pet.ether $60-80^{\circ} \mathrm{C}(2: 8, v / v)$, as yellow crystals, $\mathrm{mp}=145^{\circ} \mathrm{C}$ (66\%). Anal. Calcd for $\left[\mathrm{C}_{36} \mathrm{H}_{35} \mathrm{~N}_{2} \mathrm{O}_{2} \mathrm{P}, 558.65\right]$. C, 77.40; H, 6.31; N, 5.01; P, 5.54. Found: 77.23; H, 6.11; N, 5.43; P, 5.10. IR (KBr, cm $\left.{ }^{-1}\right): 3210(\mathrm{NH}), 1765$ $(\mathrm{C}=\mathrm{O}$, alicyclic carbonyl $), 1672(\mathrm{~N}-\mathrm{C}=\mathrm{O})$, and $1379 \mathrm{~cm}^{-1}$ (P-Phenyl). ${ }^{1} \mathrm{H}$ NMR (DMSO, $\delta$ ppm): $0.98\left(\mathrm{~s}, 3 \mathrm{H}, \mathrm{CH}_{3}\right), 1.13\left(\mathrm{~s}, 6 \mathrm{H}, 2 \mathrm{CH}_{3}\right), 1.47-1.59\left(\mathrm{~m}, 2 \mathrm{H}, \mathrm{CH}_{2}\right)$, 1.65- $1.84\left(\mathrm{~m}, 2 \mathrm{H}, \mathrm{CH}_{2}\right), 2.62(\mathrm{~m}, \mathrm{H}, \mathrm{CH}), 7.14-7.28(\mathrm{~m}, 20 \mathrm{H}$, aromatics), and $11.86 \mathrm{ppm}\left(\mathrm{s}, \mathrm{H}, \mathrm{NH}\right.$, exchangeable with $\left.\mathrm{D}_{2} \mathrm{O}\right) .{ }^{13} \mathrm{C}$ NMR (DMSO, $\delta \mathrm{ppm}$ ): 18.59 $\left(\mathrm{CH}_{3}\right), 20.66\left(2 \mathrm{CH}_{3}\right), 26.11,30.30\left(2 \mathrm{CH}_{2}\right), 47.32\left(\underline{\mathrm{C}}-\left(\mathrm{CH}_{3}\right)_{2}\right), 49.98\left(\underline{\mathrm{C}}-\mathrm{CH}_{3}\right)$, $35.33(\mathrm{CH}), 144.45(\mathrm{C}=\mathrm{P}), 164.46(\mathrm{~N}-\mathrm{C}=\mathrm{O})$, and $203.92 \mathrm{ppm}(\mathrm{C}=\mathrm{O}$, alicyclic $)$. MS: $\mathrm{m} / \mathrm{z}=[256$ (substrate) $43.76 \%]$.

Reaction of 3-(hydroxyimino)-1,7,7-trimethyl bicyclo [2.2.1] heptan-2-one (16) with active phosphacumulenes $(2 a$ and $2 b)$. Preparation of the phosphanylidenes $17 a$ and $b$.

A mixture of oxime (16) $(0.18 \mathrm{~g}, 0.001 \mathrm{~mol})$, and (N-phenyliminovinylidene)$(2 \mathrm{a})^{(26)}(0.37 \mathrm{~g}, 0.001 \mathrm{~mol})$ or (2-oxovinylidene)-triphenylphosphorane $(2 \mathrm{~b})^{(26)}$ $(0.30 \mathrm{~g}, 0.001 \mathrm{~mol})$ in dry toluene $30 \mathrm{ml}$ was refluxed for $8 \mathrm{hr}$ when $2 \mathrm{a}$ was used and for $12 \mathrm{hr}$ with $2 \mathrm{~b}$. Toluene was distilled off and the residue was chromatographed on silica gel to give the phosphanylidenes (17a and 17b), respectively.

1,7,7- (Trimethyl - (\{[(N-phenyl -2- (triphenyl - $\lambda^{5}-$ phosphanylidene $)$ ethanimidoyl] oxy]imino) - bicyclo[2.2.1] heptan-2-one (17a).

Eluent: pet.ether $60-80^{\circ} \mathrm{C}$, ethyl acetate $(7: 3, v / v)$ as yellow crystals, $\mathrm{mp}=105^{\circ} \mathrm{C}(75 \%)$, from cyclohexane. Anal.Calcd for $\left[\mathrm{C}_{36} \mathrm{H}_{35} \mathrm{~N}_{2} \mathrm{O}_{2} \mathrm{P}, 558.65\right] . \mathrm{C}$, 77.40; H, 6.31; N, 5.01; P, 5.54. Found: C, 77.13; H, 6.13; N, 5.00; P, 5.41.

1,7,7-Trimethyl -3-(\{[(triphenyl $-\lambda^{5}$-phosphanylidene) acetyl] oxy\}imno ) bicyclo[ 2.2.1] heptan- 2- one (17b)

Eluent: pet.ether $60-80^{\circ} \mathrm{C}$, ethyl acetate $(7: 3, v / v)$ it was obtained as yellow crystals, $\mathrm{mp}=125^{\circ} \mathrm{C}(65 \%)$, from cyclohexane. Anal. Cald for $\left[\mathrm{C}_{30} \mathrm{H}_{30} \mathrm{NO}_{3} \mathrm{P}\right.$, 483.54] C, 74.52; H, 6.25; N, 2.90; P, 6.41. Found: C, 74.32; H, 6.11; N, 2.53; P, 6.20 .

${ }^{1} \mathrm{H}$ NMR $\left(\mathrm{CDCl}_{3}, \delta \mathrm{ppm}\right): 0.98\left(\mathrm{~s}, 3 \mathrm{H}, \mathrm{CH}_{3}\right), 1.24\left(\mathrm{~s}, 6 \mathrm{H}, 2 \mathrm{CH}_{3}\right), 1.32-1.57(\mathrm{~m}$, $\left.2 \mathrm{H}, \mathrm{CH}_{2}\right), 1.63-1.83\left(\mathrm{~m}, 2 \mathrm{H}, \mathrm{CH}_{2}\right), 2.48(\mathrm{~m}, \mathrm{H}, \mathrm{CH}), 3.84(\mathrm{~d}, \mathrm{H}, \mathrm{CH}=\mathrm{P}$, $\left.{ }^{2} \mathrm{~J}_{\mathrm{HP}}=23.9 \mathrm{~Hz}\right), 7.44-7.71(\mathrm{~m}, 15 \mathrm{H}$, aromatics $) .{ }^{13} \mathrm{C} \mathrm{NMR}\left(\mathrm{CDCl}_{3}, \delta \mathrm{ppm}\right)$ : 14.34 $\left(\mathrm{CH}_{3}\right), 21.30\left(2 \mathrm{CH}_{3}\right), 22.72,29.72\left(2 \mathrm{CH}_{2}\right), 44.53(\mathrm{CH}), 47.64\left(\underline{\mathrm{C}}-\left(\mathrm{CH}_{3}\right)_{2}\right)$, 
54.21 $\left(\underline{\mathrm{C}}-\mathrm{CH}_{3}\right), 57.52(\mathrm{C}=\mathrm{P}), 156.23(\mathrm{C}=\mathrm{P}), 166.23(\mathrm{C}=\mathrm{N}), 176.12(\mathrm{~N}-\mathrm{C}=\mathrm{O})$, 202.51(C=O, alicyclic carbonyl). MS: $\mathrm{m} / \mathrm{z}=\left[221\left(\mathrm{M}^{+}-\mathrm{PPh}_{3}\right) 9.65 \%\right], 181\left(\mathrm{M}^{+}-\right.$ ylide) $96.71 \%$ ].

Reaction of camphorquinone 1 with the stabilized phosphonium ylide (6a). Prepation of the 3 products $(8,10$, and 12).

A mixture of $1(0.16 \mathrm{~g}, 0.001 \mathrm{~mol})$ and methoxycarbonyl methylenetriphenyl phosphorane $(6 \mathrm{a})^{(29)}(0.67 \mathrm{~g}, 0.002 \mathrm{~mol})$ was boiled in dry toluene $(30 \mathrm{ml})$ for $8 \mathrm{hr}$. The solvent was distilled off and the residue was chromatographed on silica gel using pet. ether $60-80^{\circ} \mathrm{C} /$ acetone as an eluent, affording 3 adducts $(8,10$, and 12) respectively, alongwith triphenylphosphine and triphenylphosphine oxide.

Methyl-4,7,7-trimethyl-2,2-2- triphenyl -3-oxospiro[bicyclo[2.2.1] heptane2,4-[1,2]oxa-phosphetane]-3-carboxylate (8)

Eluent: pet.ether $60-80{ }^{\circ} \mathrm{C} /$ acetone $(8: 2, v / v)$ it was obtained as yellow crystals $(40 \%)$. Anal. Calcd for $\left[\mathrm{C}_{31} \mathrm{H}_{33} \mathrm{O}_{4} \mathrm{P}, 500.57\right] \mathrm{C}, 74.38 ; \mathrm{H}, 6.64 ; \mathrm{P}, 6.19$. Found: C, 74.21; H, 6.30; P, 6.11.

Dimethyl-2-(4,7,7-trimetyl-3- oxobicyclo [2.2.1] hept-2-yl-3- (triphenyl- $\lambda^{5}-$ phosphanylidene)-butanedioate (10)

Eluent: pet.ether $60-80{ }^{\circ} \mathrm{C} /$ acetone $(7: 3, v / v)$ it was obtained as yellow crystals $(25 \%)$. Anal. Calcd for $\left[\mathrm{C}_{34} \mathrm{H}_{37} \mathrm{O}_{5} \mathrm{P}, 556.63\right] \mathrm{C}, 73.36 ; \mathrm{H}, 6.70 ; \mathrm{P}, 5.56$. Found: C, 73.16; H, 6.32; P, 5.31

Methyl-1,11,11-trimethyl-4-oxo-3-oxatricyclo[6.2.1.0 $\left.0^{2,7}\right]$ undeca-2(7),5-diene6-carb-oxylate (12).

Eluent: pet.ether $60-80{ }^{\circ} \mathrm{C} /$ acetone $(6: 4, v / v)$ it was obtained as yellow crystals (15\%) Anal Calcd for $\left.\mathrm{C}_{15} \mathrm{H}_{18} \mathrm{O}_{4}, 262.30\right] \mathrm{C}, 68.68 ; \mathrm{H}, 6.92$. Found: $\mathrm{C}$, $68.31 ; \mathrm{H}, 6.63$.

Reaction of camphorquinonephenylhydrazone (13) with stabilized phosphonium ylides (6a and $b$ ).

Camphorquinonephenylhydrazone (13) $(0.26 \mathrm{~g}, 0.001 \mathrm{~mol})$ was added to a solution of methoxycarbonyl- $(6 \mathrm{a})^{(29)}(0.33 \mathrm{~g}, 0.001 \mathrm{~mol})$ or ethoxycarbonylmethylenetriphenylphospho- rane $(6 \mathrm{~b})^{(29)}(0.34 \mathrm{~g}, 0.001 \mathrm{~mol})$ in dry toluene $(30 \mathrm{ml})$, and the reaction mixture was refluxed for $10 \mathrm{hr}$ in case of $6 \mathrm{a}$ and $12 \mathrm{hr}$ when $6 \mathrm{~b}$ was used. The solvent was distilled off under reduced pressure; the residue was applied to silica gel column chromatography to afford compounds $15 \mathrm{a}$ and $15 \mathrm{~b}$, respectively.

4,7,7-Trimethyl-methyl 2,2,2-triphenyl-1- (methylamino)-3-oxospiro[1,2azaphophetidine-4, 2-bicyclo[2.2.1] heptane]-3-carboxylate (15a).

Eluent: acetone / pet.ether $60-80{ }^{\circ} \mathrm{C}(2: 8, v / v)$, as yellow crystals, $\mathrm{mp}=166$ ${ }^{\circ} \mathrm{C}(65 \%)$. Anal. Calcd for $\left[\mathrm{C}_{37} \mathrm{H}_{39} \mathrm{~N}_{2} \mathrm{O}_{3} \mathrm{P}, 590.69\right]$. C, 75.23; H, 6.65; N, 4.74; $\mathrm{P}$, 5.24. Found: C, 75.01; H, 6.32; N, 4.63; P, 5.13.

Egypt. J. Chem. 53, No. 2 (2010) 
4,7,7-Trimethyl- ethyl2,2,2-triphenyl -1- (methylamino)-3-oxospiro[1,2azaphosphetidine-4,2-bicyclo[2,2,1]heptane]-3-carboxylate (15b).

Eluent: acetone / pet.ether $60-80^{\circ} \mathrm{C}(3: 7 \mathrm{v} / \mathrm{v})$, yellow crystals, $\mathrm{mp}=135{ }^{\circ} \mathrm{C}$ (67\%). Anal. Calcd for $\left[\mathrm{C}_{38} \mathrm{H}_{41} \mathrm{~N}_{2} \mathrm{O}_{3} \mathrm{P}, 604.72\right] \mathrm{C}, 75.47 ; \mathrm{H}, 6.83 ; \mathrm{N}, 4.63 ; \mathrm{P}$, 5.12. Found: C, 75.26; H, 6.44; N, 4.31; P, 5.00. IR $\left(\mathrm{KBr}, \mathrm{cm}^{-1}\right): 3100(\mathrm{NH})$, $1713\left(\mathrm{C}=\mathrm{O}\right.$, alicyclic carbonyl), $1692(\mathrm{~N}-\mathrm{C}=\mathrm{O}), 1492 \mathrm{~cm}^{-1}$ (P-Phenyl). ${ }^{1} \mathrm{H}$ NMR (CDCl, $\delta$ ppm): 0.89 (s, 3H, $\left.\mathrm{CH}_{3}\right), 1.11\left(\mathrm{~s}, 6 \mathrm{H}, 2 \mathrm{CH}_{3}\right), 1.29\left(\mathrm{t}, 3 \mathrm{H}, \underline{\mathrm{CH}}_{3} \mathrm{CH}_{2}\right.$ ), 1.36-1.48 (m, 2H, $\left.\mathrm{CH}_{2}\right), 1.53-1.72\left(\mathrm{~m}, 2 \mathrm{H}, \mathrm{CH}_{2}\right), 2.25(\mathrm{~m}, \mathrm{H}, \mathrm{CH}), 2.84(\mathrm{~d}, \mathrm{H}$, CH-P), 4.21 (q, 2H, $\mathrm{CH}_{3} \underline{\mathrm{CH}}_{2}$ ), 6.56-6.69 (m, 5H, aromatic), 7.13-7.45 (m, 15H, aromatic), $11.54 \mathrm{ppm}\left(\mathrm{s}, \mathrm{H}, \mathrm{NH}\right.$, exchangeable with $\left.\mathrm{D}_{2} \mathrm{O}\right) . \mathrm{MS}: \mathrm{m} / \mathrm{z}=\left[342\left(\mathrm{M}^{+}-\right.\right.$ $\left.\mathrm{PPh}_{3}\right)$ 5.34\%, 262( $\left.\mathrm{PPh}_{3}\right) 56.43 \%$, and 256 (substrate 13) 85.22\%].

Reaction of camphorquinone monooxime (16) with stabilized phosphonium ylides ( $6 a$ and $b)$.

Camphorquinone monooxime (16) $(0.18 \mathrm{~g}, 0.001 \mathrm{~mol})$ was added to a solution of methoxycarbonyl- (6a) $(0.37 \mathrm{~g}, 0.001 \mathrm{~mol})$ or ethoxycarbonylmethylenetriphenylphosphorane $(6 \mathrm{~b})(0.34 \mathrm{~g}, 0.001 \mathrm{~mol})$ in dry toluene $(30 \mathrm{ml})$, and the reaction mixture was refluxed for $8 \mathrm{hr}$. The solvent was distilled off under reduced pressure and the residue was applied to silica gel column chromatography using pet.ether $60-80{ }^{\circ} \mathrm{C} / \mathrm{ethyl}$ acetate as eluent $(6: 4, \mathrm{v} / \mathrm{v})$ to afford compound 19 , and triphenylphosphine oxide. (19),

1,11,11-trimethyl-3-oxa-6-azatricyclo [6.2.1.0 $\left.0^{2,7}\right]$ undeca-2 (7), 5-dien-4-one

It was isolated as colorless crystals, $\mathrm{mp}=115^{\circ} \mathrm{C}(55 \%)$. Anal. Calcd for $\left[\mathrm{C}_{12} \mathrm{H}_{15} \mathrm{NO}_{2}, 205.25\right] \mathrm{C}, 70.22 ; \mathrm{H}, 7.37 ; \mathrm{N}, 6.82$. Found: C, 70.13; H, 7.21; $\mathrm{N}, 6.53$.

\section{References}

1. Potts, T. V. and Petrou, A., Laser Surg. Med. 11 (3), 257-26 (1991).

2. Nakazato, J. and Wakumoto, K. I., Dent. Mater. J. 8(2), 147 (1998).

3. Neumann, M. G., Schmitt, C. C., Correa, I. C. and Goi, B. E., J. Braz. Chem. Soc. 19 (7), 1413 (2008).

4. Nikaido, T., Podszun, W., Muller, M. and Nakabayashi, N., Dent. Mater. J. 6(2), 78 (1990).

5. Asmussen, E., Antonucci, J. M. and Bowen, R. L., Scand. J. Dent. Res. 96 (6), 584 (1988).

6. Kato, G. and Nakabayashi, N., Dent. Mater. J. 12(4), 250 (1996).

7.Watanabe, I. and Nakabayashi, N., Quintessence Int. 24 (5), 335 (1993). 
8. Soliman, F. M., Said, M. M. and Maigali, S. S., Heteroatom Chem. 16(6), 476-48 (2005).

9. Said, M. M., Maigali, S. S., Abd-El-Maksoud, M. A. and Soliman, F.M., Monatsh. Chem. 139 (2008).

10. Maigali, S.S., Said, M. M., Abd-El-Maksoud, M. A. and Soliman, F. M., Monatsh. Chem. 139, 496-501 (2008)

11. Shabana, R., Maigali, S. S., Essawy, S. A., EL-Hussieny, M. and Soliman, F. M. Egypt J. Chem. (Special Issue M. Sidky), 59-67 (2007).

12. Maigali, S. S., Shabana, R., EL-Hussieny, M. A. and Soliman, F.M., Phosphorus Sulphur and Silicon and the Related Elements, 184, 2408-2426 (2009).

13. Soliman, F. M., Abd-Ellah, I. M., Maigali, S. S. and Abd-Elnaim, G., J. Chem. Res. 277 (2009).

14. Maigali, S. S. and Soliman, F. M., J. Res. Trends, Accepted (2010).

15. Soliman, F. M., Khalil, Kh. M., Said, M. M. and Maigali, S. S., Heterocyclic Comm. 8 (5), 451 (2002).

16. Soliman, F. M., Said, M. M. and Maigali, S. S., Monatsh. Chem. 136, 241 (2002).

17. Williams, D. H. and Fleming, I. F., Spectroscopic Methods in Organic Chemistry, Mc Graw-Hill Book Company, Maidenhead, Berkshire UK 55 (1987).

18. Grim, S. O., McFarlane, W. and Marks, T. J., Chem. Commun. 1191 (1967).

19. Bestmann, H. J. and Zimmermann, R., Organic Phosphorus Compounds, Vol.3 (1972). Kosolapoff, G. M., Maier, L. (Ed.) John Wiley and Sons, Inc. Wiley, New York C. A.,78, 84461x (1973).

20. Mattews, C. N. and Birum, G. H., Acc. Chem. Res. 2, 373 (1969).

21. Vedejis, E. and Snoble, K. A. J., J. Am. Chem. Soc. 95, 5778 (1973).

22. Schlosser, M., Piskala, A., Tarchini, C. and Tuony, H. B., Chimia, 29, 341 (1975).

23. Bestmann, H. J. and Schmid, G., Angew Chem. Int. Ed. Engl. 13, 273 (1974).

24. Augustin, M. and Jeschke, P., J. Prakt. Chem. 329, 637 (1987).

25.White, J.D., Wardrop, D.J. and Sundermann, K.F., Organic Syntheses, 79, 125 (2002).

26. Bestmann, H. J. and Schmid, G., Tetrahedron, 4025 (1957).

27. Michaels, A. and Gleichmann, L., Chem. Be. 15, 81 (1882).

Egypt. J. Chem. 53, No. 2 (2010) 
28. Bestmann, H. J. and Sandmeier, D., Angew Chem. Int. Edit. 14, 634 (1957).

29. Bestmann, H. J. and Kratzer, O., Chem. Ber. 95, 1894 (1962).

(Received $14 / 4 / 2010$, accepted 9/5/2010)

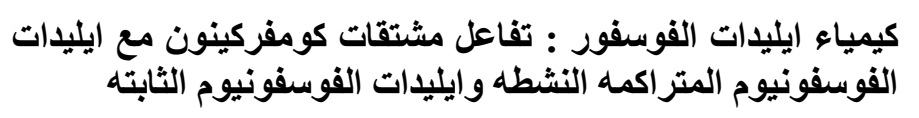

سهير سعيد مجلى ، هدى أنور عبد الملك و فؤاد محمد سليمان

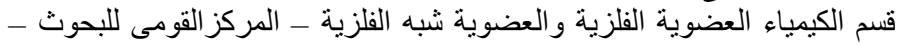
الجيزة - مصر الكياء العبو

فى هذا البحث تم دراسة تفاعلات مركبات الكومفركينون (1) (1) ، أحادى فينيل

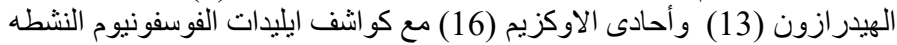

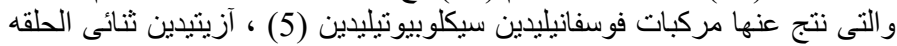

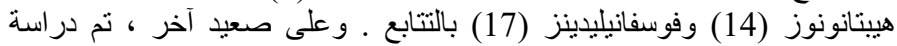

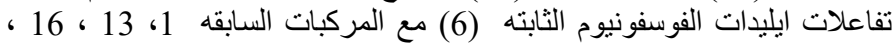

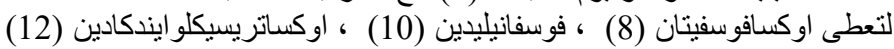

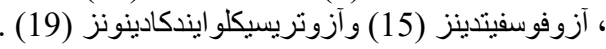

وقد تأيدت التركيبات البنائيه المقترحه للنواتج الجديده بواسطة الاساليب التحليليه و الطيفيه . تابدت 
